\title{
A CASE OF PERFORATED DUODENAL ULCER IN AN INFANT
}

BY

L. PRISCILLA HARRISON, M.B., B.S.

(From the Royal Free Hospital, London.)

The following case of perforated duodenal ulcer in an infant is reported, not only on account of the rarity of the condition, but also because the symptoms and course presented differ somewhat from those in previously reported cases.

Peptic ulcers are evidently not very rare in infants under one vear of age, but only a few have been recorded in England. In Welch's 's collection of 607 cases of peptic ulcer only one occurred under ten years of age. Koplik ${ }^{2}$ reported one case of peptic ulcer out of 300,000 cases of diseases of children, and Rokitansk $\mathbf{y}^{3}$ stated that he never saw a case under fourteen vears. In 1926 Theile 4 collected 248 cases of peptic ulcers in children; 138 of these occurred in the first year, and one-third of the entire series in the first month of life ; 58 per cent. were duodenal and 42 per cent. gastric. Altogether, duodenal seem to occur more frequently than gastric ulcers. In 364 autopsies under one year $\mathrm{Entz}^{\mathbf{5}}$ found ten duodenal and only one gastric ulcer. Females are more commonly affected than males.

The age incidence seems to correspond to that of marasmus. Holt ${ }^{6}$ in 65 cases noted that 70 per cent. occurred between six weeks and fire months.

Perforation.-Although over $\mathbf{2 0 0}$ cases of duodenal ulcer in infants have been recorded in the literature, only nine cases of perforation have been found. Nevertheless, Adler ${ }^{2}$ remarks on the large percentage of perforations which occur in acute ulcers in children.

The following have each reported one case of perforated duodenal ulcer in infants under one year : Borland ${ }^{8}$, Adriance ${ }^{9}$, Finny $y^{-10}$, Helmholz $^{11}$, Griffith $^{12}$, Schmidt ${ }^{13}$, and Somerford ${ }^{14}$. Entz ${ }^{5}$ has recorded two instances.

\section{Case report.}

T.L., a female infant, born on December 25th, 1930, was admitted to the Roval Free Hospital under the care of Dr. Chodak Gregory on Feb. 24th, 1931. The child had been born three weeks premature by instrumental delivery. She was the second child in the family. Birth weight $8 \frac{1}{2} \mathrm{lb}$. She had been breast fed 3-hourly from birth, and had been treated at Moorfields Hospital for ophthalmia neonatorum.

At 9.0 p.m. on February 22nd, the baby suddenly started to scream and draw up its legs. Similar attacks followed in quick succession. Next morning at $4.0 \mathrm{a}$.m. the mother noticed that the abdomen was distended. This distension steadily increased. There was no romiting; the stools were perfectly normal and the baby continued to take well.

On admission the temperature $96^{\circ}$, pulse 130 , and respirations 40 . The baby was markedly wasted, only weighing $; \mathrm{lb}$. $2 \mathrm{oz}$. The face was pale and drawn. The anterior fontanelle was large and depressed, the posterior fontanelle still present, the occipital and frontal bones some what bossed and the sutures too prominent. The palate was high and narrow, the eves slanterl 
vertically especially the right, and both showed scars of ophthalmia neonatorum. Some nasal discharge was observed.

The abdomen was tense and distended and the umbilicus unfolded (Fig. 1). Dilated reins were seen in the upper part of the abdominal wall. There was no visible peristalsis, nor were any organs palpable on account of the distension. The percussion note, althougb tympanitic, was impaired in the flanks, but no shifting dullness or fluid thrill was detected. The liver dullness was normal : nothing abnormal was found on rectal examination.

The distension of the abdomen rapidly increased and the abdominal wall became tense and shinys and finally œedematous and red. Edema also appeared in the scalp.

The baby continued to take well ; there was no vomiting at any time, the stools were normal in colour but relaxed, four to nine motions being passed daily, and there was no melæna. The child slept well and did not cry, although the face always wore an anxious expression.

The temperature remained normal throughout, with the exception of the second day after admission when there was a temporary rise to $101 \cdot 4^{\circ}$.

On March 4th the abdomen was explored as signs of free fluid had developed; the resulting fluid on examination appeared to consist of contents of the small intestine.

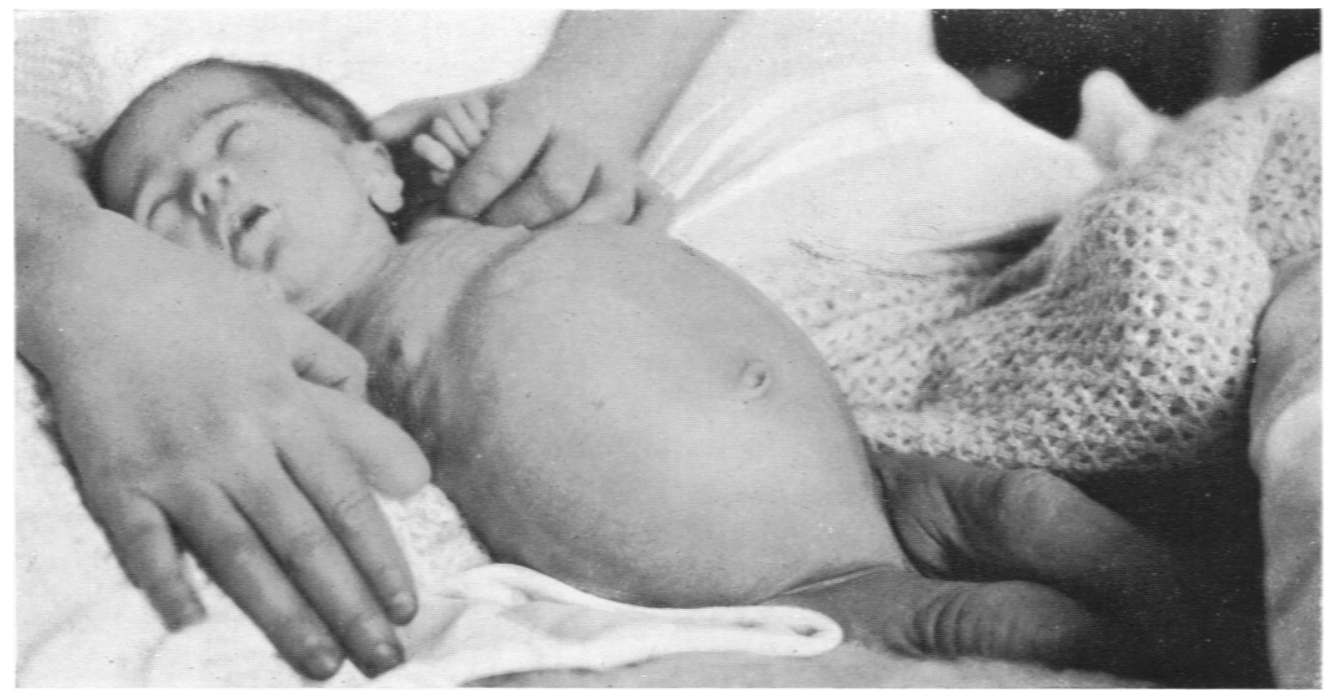

Fig. 1. Condition 4 days after admission. Note the extreme distension of the abdomen; also the dilated veins.

Just before death the circumference of the abdomen decreased from $17 \cdot 2$ in. to $16 \cdot 5$ in.

The child died on March 5th, eleven days after the onset of the symptons, at the age of ten weeks.

Investigations.-Nasal swab. Friedlander's pneumobacillus was found to be the predominating organism on culture. No gonococci were seen. The Wassermann reaction and Kahn test were negative. Fluid withdrawn from peritoneal cavity. Direct film showed very degenerate cells, numerous large gram-positive sporing bacilli, some gram-negative bacilli and a few gram-positive cocci in short chains. On culture there were B. coli, B. welchii, and anærobic streptococci. Chemical examination of the fluid showed that bile was present, also trypsin and fat. The diastase index was over 50 , showing the presence of pancreatic secretion and therefore suggestive of the contents of the small intestine.

Post-mortem examination.-A wasted child with a very distended abdomen, on opening which some gas escaped. The peritoneal cavity was found to contain yellowish fluid, also some curdy material of a similar colour, evidently stomach contents mixed with bile, lying anteriorly to the stomach and left lobe of the liver. On breaking down adhesions the jejunum and ileom 


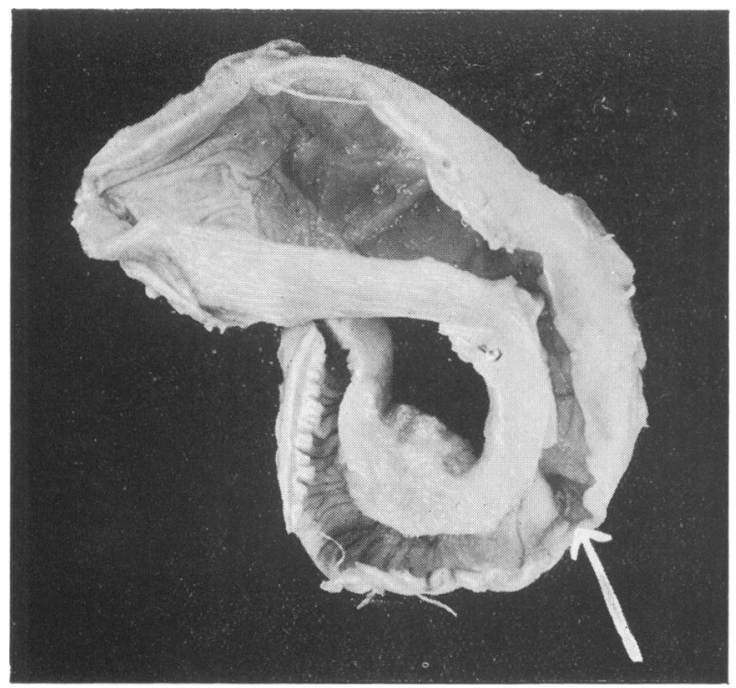

Fiti. 2. Stomach laid open to show the hypertrophy of the musculature. The ulcer is denoted by arrow.

were found to be normal. An ulcer about $\frac{1}{2}$-inch in diameter was found just distal to the pylorus on the posterior wall of the duodenum (Fig. 2). The edges of the ulcer were over-hanging, the base showed no perforation and was not very indurated, but the appearances suggested that the ulcer had perforated and had subsequently healed. There was considerable hypertrophy of the pyloric musculature and also of the stomach wall. Another small acute ulcer was present in the pyloric region of the stomach. The other organs showed no changes of importance.

Microscopically the ulcer showed rolling of the mucous membrane at the margins. The floor consisted of the muscle coat covered by a thin layer of granulation tissue. Extension by

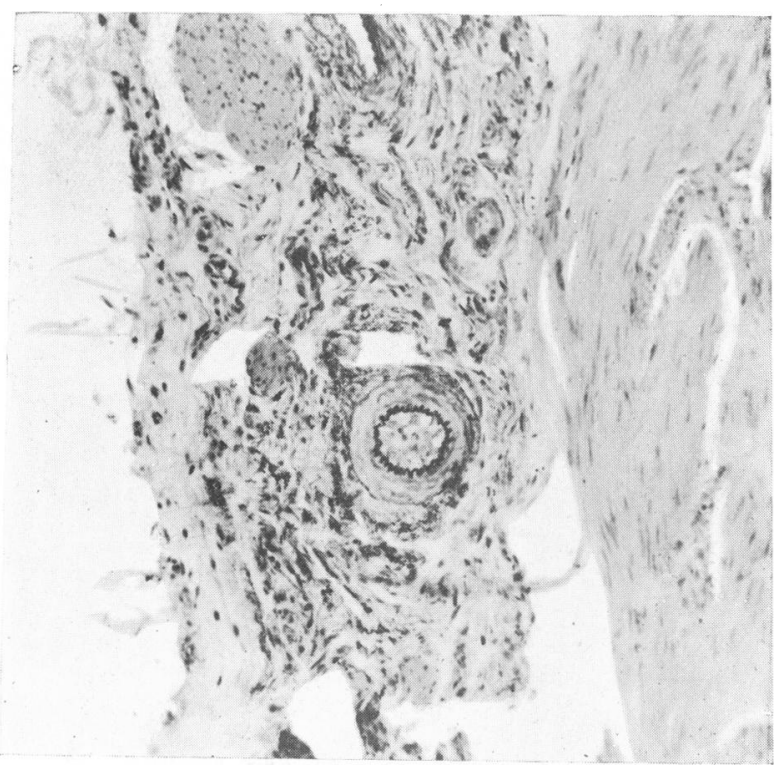

Firi. 3. Microphotograph of the base of the ulcer. Note vessel showing complete obliteration of the lumen by proliferation of intima. Stained Weigert's elastic stain and hæm-alum and eosin. 
Etiology.-Study of the literature suggests that the causes predisposing to peptic ulceration are lowered general vitality and previous digestive disturbance. Vascular changes seem to be of chief importance as a determining cause, a small hæmorrhage being followed br gastric digestion of the infarcted area. Shore ${ }^{15}$ groups the causes of rascular disturbance into congestion, embolism, thrombosis, direct rascular injury and diseases of the nerrous sistem. Other ætiological factors which have been suggested are: prenatal disposition (Jacobi $\left.{ }^{16}\right)$, tuberculosis, hrperacidity, bacterial necrosis, burns (Paterson $\left.{ }^{17}\right)$ and anatomical abnormalities $\left(\right.$ Rogers $\left.^{18}\right)$.

Peptic ulcers which have caused no definite symptoms during life are sometimes found at post-mortem examinations of marasmic infants. The large majority of these ulcers are single and it is very rare to find more than three in any one infant.

In the present case microscopic examination showed definite vascular lesions which may justifiably be regarded as the direct cause in initiating the peptic digestion of the devitalised mucosa.

Situation.-Duodenal ulcers are alwars found to be above the papilla of Vater on the posterior wall of the duodenum, and just below the pyloric ring.

The ulcer is usually punched out. Both round-celled infiltration and induration are uncommon. Holt ${ }^{6}$ has observed that this condition is quite often associated with prlorospasm and congenital prloric stenosis.

Symptoms. - It has been stated that the symptoms may be absent singly or collectirely, or may be latent. Perforation and subsequent peritonitis often give rise to the first symptoms, death usually occurring in less than 36 hours. According to $\mathrm{Holt}^{6}$ one-third of all cases give no simptom of ulcer.

Hæmatemesis and melæna are the most characteristic simptoms. Other cases show continual romiting and gastro-intestinal symptoms. On examination there are commonly pain and tenderness in the epigastrium.

In the case described death did not superrene until eleven days after the ulcer perforated. Hæmatemesis and melæna were both absent, nor was there any romiting. The child did not cry on palpation of the epigastrium.

\section{Summary.}

1. A case of duodenal ulcer in a female infant, aged 10 weeks, is described.

2. There is no doubt that the ulcer had perforated, probably on February 2.2nd, and that before death the perforation had closed. This is perhaps the most remarkable feature of the case.

3. The afebrile course is probably explained by the fact that the duodenal contents escaping into the abdominal cavity were nearly sterile and the peritonitis set up was non-infective, being due to the mechanical irritation caused by the presence of food.

4. The absence of melæna is probably due to the fact that the ressels in the floor of the ulcer were no longer patent, only a few capillaries retaining their lumen.

5. In this case marked endarteritis and periarteritis occurred in the ressels supplying the ulcerated area. 
My thanks are due to Dr. Chodak Gregory for allowing me to use the notes of this case and for her invaluable help and advice; also to Dr. Ross for the photographs and pathological reports.

\section{REFERENCES.}

1. Welch. W. H.. Pepper's System of Medicine, 1885, II, 480.

$\rightarrow$ Koplik, quoted by Lockwood, C.D., Surg. Gynec. Obst., (hicago, 1914, XIX, $46:$

3. Rokitansky, C., quoted by Stowell, W. L., Med. Rec., 1905, LXVIII, 5:-

4. Theile. P., Ergebn. der Inn. Med. und Kinderh., Berlin. 1919, XVI, 30-2.

5. Entz. quoted by Flesch. Jahrb. f. Kinderh.. Berlin, 1912. LXXVI, 542

6. Holt, L. E.. Am. J. Dis. Child., Chicago. 1913, VI, 381.

¡. Adler. H.. A w. J. Jed. Sc., Chicago, 1907, CXXXiII, 13.j.

8. Borland. H. H., Lancet. London. 1903, ii. 1084.

9. Adriance. V.. Arch. Ped., X.Y.. 1901, XVIII, ․27.

10. Finny, (. E.. Prox. Roy. Sx. Med., London, 1909, II. (Sert. Dis. Child.), 67.

11. Helmholz, H. F., Arch. Ped.. X.Y.. 1909. XXVII, 661.

12. Griffith, C., N.Y. Med. J., X.Y., 1911, XCIV, 572.

13. Schmidt, Berlin Klin. Wehnschr., Berlin, 1913, XIII, 593.

14. Somerford, A. F., Lancet, Lond., 1930, i. 1015.

15. Shore. B. R., Ann. Surg., 1930, XCII, 234.

16. Jacobi. X.Y. Med. J. X.Y. 1909, XC. 837.

17. Paterso ר. D., Lancet, Lond., 1922, i, 60.

18. Rogers J. s. Y., Arch. Dis. Childh., Lond., 19:28, III, 163 